\title{
Ground Water Management in Godavari Basin
}

\author{
S. A. Nagre, Expert Member Marathwada Development Board, Aurangabad, (M.S.) India. \\ nagre.shankar96@gmail.com
}

\section{Dr. S.T. Sangle, Former Professor and Head Dr. Babasaheb Ambedkar Marathwada University, Aurangabad, (M.S.) India. sanglest@yahoo.co.in \\ Dr. Ashok Tejankar, Professor and Head Department of Geology, Deogiri College Aurangabad, M.S.) India.dravtejankar@gmail.com}

\begin{abstract}
The Godavari River is rising in Western Ghat near Nashik and running for a length of $1445 \mathrm{Km}$. to join the sea. Godavari is the largest river in South India, flowing through six states and joining to bay of Bangal. It has $49 \%$ catchment area in Maharashtra with 30 Sub-basins. Out of these, 3 sub-basins are lying in Nashik Region, 9 Sub-basins are in Marathwada Region, and 18 Sub-basins are in Vidharbha Region. As per the availability of surface water the category of Sub-basins in Nashik and Vidharbha Region is classified as Normal as it is having more than 3000 Cum. of Water per Hectare. However the Sub-basins in Marathwada Region are in highly deficit category, as it is having the water of only $1181 \mathrm{Cum}$. per Hectare. Nearly $92 \%$ area of the state is occupied by the hard rock including $82 \%$ of basalt and $10 \%$ of Metamorphic rocks. Maharashtra state is having total 807 nos. of water sheds with 12249 Mcum. Ground Water available. Out of these net 3752 Mcum. Of Ground Water is available for future use. It is estimated that about 271719 of additional wells can be taken up in the state under Godavari Basins.
\end{abstract}

Keywords: Ground Water, Surface Water, Rocks Classification

\section{INTRODUCTION}

The Godavari river is the largest river in Southern India. The river originates at RL. $1067 \mathrm{mt}$. near Trimbakeshwar $\left(19^{\circ} 55^{\prime} 47^{\prime \prime} \mathrm{N}\right.$ and $73^{\circ} 31$ ' 22" E) in Brahmagiri ranges in the Sahyadri hills named as western Ghat in Nashik District and meets sea at Bay of Bengal in Andhra Pradesh State. Total length of the Godavari River is $1445 \mathrm{~km}$ out of which length within Maharashtra state is $694 \mathrm{~km}$. Godavari Basin extends over states of Maharashtra, Telangana, Andhra Pradesh, Chhattisgarh, and Orissa in addition to smaller parts in Madhya Pradesh, Karnataka and union territory of Podduchery. The basin has the total drainage area of 3,12,800 Sq.km. The basin has a length of about $995 \mathrm{~km}$ and width of about 583 and occupies nearly $9.5 \%$ of the total geographical area of the country and is the largest river basin in the peninsular India. The Godavari river basin covers the drainage area of $1,52,587$ sq.km. i.e. about $49 \%$ of the total Godavari catchment area in Maharashtra State. The basin is bounded by the western Ghats on the west side with Satmala hills, Ajantha ranges and Mahadev hills on the north, low hill ranges in the south along with eastern Ghats in the east.

\section{OBJECTIVE}

1. To study the salient features of Godavari basin

2. To study the Geo-hydrology of Godavari basin

3. To study the Ground Water availability

in Godavari basin

\section{METHODOLOGY}

Only secondary data like books, research paper reports of water commission, GWP and ISWP are used for the present research paper.

\section{STATE WISE COVERAGE}

The catchment area of the entire Godavari basin covers six states. The Sate wise area is given below.

Table No. 1 State wise Percentage of Catchment Area

\begin{tabular}{|c|c|c|c|}
\hline Sr. No. & State & C.A. in Sq. Km & Percent \% \\
\hline 1 & Maharashtra & 152587 & 49 \\
\hline 2 & Madhya Pradesh & 26168 & 8 \\
\hline 3 & Chhattisgarh & 39087 & 13 \\
\hline 4 & Orissa & 17752 & 6 \\
\hline 5 & Karnataka & 4406 & 1 \\
\hline 6 & $\begin{array}{l}\text { Telangana } \\
\text { (old AP) }\end{array}$ & 72800 & 23 \\
\hline & Total & 312800 & 100 \\
\hline
\end{tabular}


Source: GoM (2017), “Integrated State Water Plan For Godavari Basin of Maharashtra”, WRD, Volume No. 1 Page No. 107

The above table explains the state wise catchment area in Godavari basin in each state along with its percentage. It is clear from the above table that Maharashtra is having maximum (49 per cent) catchment area in Godavari basin and the Karanataka state having the minimum (only1 per cent) catchment area in Godavari basin.

Fig. 1. Map of Godavari Basin

\begin{tabular}{|c|c|c|c|c|c|}
\hline \multirow[b]{2}{*}{ Region } & \multirow{2}{*}{$\begin{array}{l}\text { Culti. Area } \\
\text { (Ha) }\end{array}$} & \multicolumn{2}{|c|}{ Surface Water } & \multirow{2}{*}{$\begin{array}{c}\text { Cum/ } \\
\mathbf{H a} \\
(\mathbf{5} / 3)\end{array}$} & \multirow[t]{2}{*}{ Category } \\
\hline & & Avail. & Allotted & & \\
\hline Nashik & 1773471 & 5773 & 5837 & 3292 & $\mathrm{~N}$ \\
\hline Marathawada & 4427526 & 7046 & 5229 & 1181 & HD \\
\hline Vidharbha & 4640247 & 25788 & 17957 & 3870 & $\mathrm{~N}$ \\
\hline $\begin{array}{l}\text { Total } \\
\text { Regions }\end{array}$ & 10841244 & 38607 & 29023 & 2677 & $\mathrm{D}$ \\
\hline
\end{tabular}

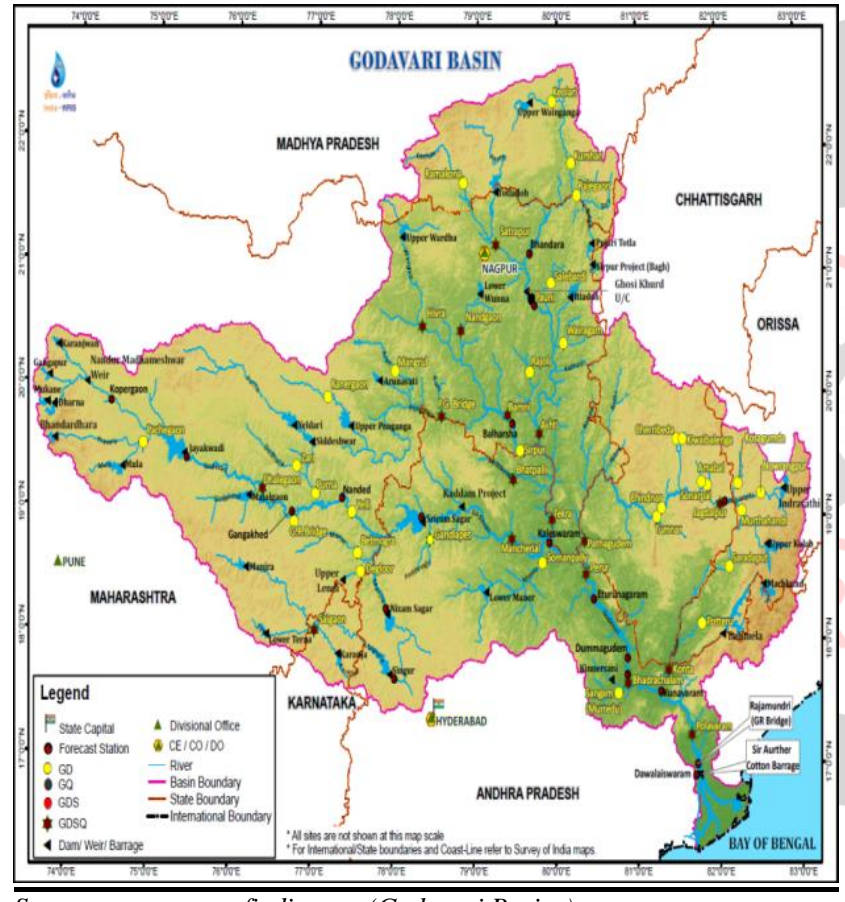

Source: www.mapsofindia.com (Godavari Basins)

\section{PARTS OF THE BASIN}

The entire Godavari basin is divided in to three regional parts, along with thirty sub-basins named from the name of the rivers of tributaries joining to the main Godavari river as below.

Table No.2 Sub basin wise Population

\begin{tabular}{|l|c|c|c|}
\hline Regional Name & Sub basin & $\begin{array}{l}\text { Drainage } \\
\text { Area } \\
\text { (Ha) }\end{array}$ & $\begin{array}{l}\text { Population } \\
\text { (2011) }\end{array}$ \\
\hline Nashik & $3 \mathrm{Nos}$ & 2191200 & 8713424 \\
\hline Maharthwada & $9 \mathrm{Nos}$ & 5187800 & 13336178 \\
\hline Vidarbha & $18 \mathrm{Nos}$ & 7879700 & 17227900 \\
\hline Godavari Basin & $30 \mathrm{Nos}$ & 15258700 & 39277502 \\
& & & \\
\hline
\end{tabular}

Source: GoM (2017), “Integrated State Water Plan For Godavari Basin of Maharashtra”, WRD, Volume No. 1 Page No. 137-156

\section{SURFACE WATER AVAILABILITY}

The yield calculated above for various dependability, is the surface water available on the ground in the number of sub basins. The yield at $75 \%$ dependability is generally considered for the design of the projects. But, whole quantity of surface of water available cannot be use in the respective sub basins for the interstate rivers like Godavari. And hence the tribunal has put some restrictions on the use of available surface water. Accordingly, the Godavari Water Disputes Tribunal (GWDT) has allowed the following sub basin wise water use in the Godavari basin.

From the above table, if the region wise classification of the basins is done, it is seen that,

1) Nashik Region : Nashik region is lying in Average or Normal category as the value of water allotted is 3292 $\mathrm{CuM} / \mathrm{Ha}$ which is more than the normal value of 3000 $\mathrm{CuM} / \mathrm{Ha}$.

2) Marathwada Region: Marathwada region is in highly deficit category as the value of the water available / allotted is only $1181 \mathrm{CuM} / \mathrm{Ha}$ i.e. less than $<1500 \mathrm{CuM} / \mathrm{Ha}$.

3) Vidarbha Region : Vidarbha region is lying in Average or Normal category as the value of water allotted is $3870 \mathrm{CuM} / \mathrm{Ha}$ which is above Normal value of 3000 $\mathrm{CuM} / \mathrm{H}$.

Even the value of water available / allotted to Nashik and Vidarbha Region is more than $500 \mathrm{CuM} /$ Capita/year, may face the scarcity conditions. But, the Marathwada Region having only $320 \mathrm{CuM} / \mathrm{Ha} /$ year of water is classified under acute or absolute scarcity as the value is less than 500 CuM/Capita; This shows that, to bring the Marathwada region out of the scarcity condition additional water will have to be transferred to this region from other surplus basins.

\section{CLASSIFICATION OF SUB-BASINS}

Maharashtra Water and Irrigation Commission (1995) has prescribed the norms of classification of basins /sub basins on the basis of surface water availability per hectare on cultivable land. Accordingly, the sub basins of the Godavari basin are classified as shown in the table given below. 
Table No. 4 Percentage wise Drainage Area

\begin{tabular}{|c|lc|c|c|}
\hline $\begin{array}{c}\text { Sr. } \\
\text { No. }\end{array}$ & \multicolumn{1}{|c|}{ Category } & $\begin{array}{c}\text { Drainage Area In } \\
\text { sqkm }\end{array}$ & Percentage \\
\hline 1 & $\begin{array}{l}\text { Highly Deficit } \\
(0-1500)\end{array}$ & 42322 & $27.8 \%$ \\
\hline 2 & $\begin{array}{l}\text { Deficit } \\
3000)\end{array}$ & $(1501-$ & 57207 & $37.5 \%$ \\
\hline 3 & $\begin{array}{l}\text { Normal } \\
8000)\end{array}$ & $(3001-$ & 47674 & $31.2 \%$ \\
\hline 4 & $\begin{array}{l}\text { Surplus } \\
12000)\end{array}$ & $(8001-$ & 5384 & -- \\
\hline 5 & $\begin{array}{l}\text { Abundant } \\
12000)\end{array}$ & -- & $100 \%$ \\
\hline 6 & \multicolumn{2}{|l|}{ Total } & 152587 & \multicolumn{2}{c|}{} \\
\hline
\end{tabular}

From the table No. 4, the overall region wise classification is as below.

1) Nashik Region: 3 nos. Sub Basins are in normal category.

2) Marathwada Region: 7 nos. Sub basins are in highly deficit category. 2 nos. Sub Basins are in deficit category.

3) Vidarbha Region: 1 no. Sub basin is highly category.

7 nos. Sub basins are in deficit category.

7 nos. Sub basins are in average category.

3 nos. Sub basins are in Surplus category.

Total

30 nos. Sub basins.

From the above analysis it is seen that, the Marathwada region is under highly deficit or deficit category and requires more water to increase the irrigation of this area.

IX. GEOLOGY AND HYDRO-GEOLOGY OF

\section{BASINS}

Maharashtra state comprises mainly of the six basins, as Godavari, Krishna, Tapi, WFR of Kokan, Narmada and Mahanadi. The Godavari basin is $68 \%$ underlain by the Deccan Trap formation. The Godavari and Krishna basin comprises of a series of basaltic lava flows of 6 to $100 \mathrm{~m}$ individual thickness. The Deccan trap exhibits step-like topography. Individual flows are generally separated by thin beds of red bole. Red bole and Green bole range in thickness between 0.5 to $1 \mathrm{~m}$ in Godavari basin and 0.2 to $1 \mathrm{~m}$ in Krishna basin, having fine graines and brick red and green in colour respectively, ferruginous and clayey in nature and indicate presence of vesicular or zeolitictrappean unit underneath. Generally, it serves as marker horizon. Red bole or Green bole acts as a marker horizon between two basaltic flows. Alluvium is found on both sides of the Godavari River and its tributaries mainly in the parts of Upper Godavari, Mula, Middle Godavari, Lendi, Dudhna, Purna, Wardha, Erai, Andhari, Venna, Kolar, Kanhan and Wainganga sub-basins ranging in depth from 2 to $23 \mathrm{~m}$ and comprises brownish clay with intercalations of gravel and kankar.

\section{GROUNDWATER POTENTIAL ZONES}

Lineaments, faults and shear-zones are promising locations for occurrence of groundwater. The pattern and intensity of fracture determine whether the groundwater occurs under unconfined conditions or under confined conditions. When fractures are vertical unconfined condition is likely to exist, but if the fractures are inclined with little inter-connections between them, then confined condition is likely to prevail in individual inclined joints. The groundwater worthy area is further sub integrated divided into three groundwater potential zones based upon hydro-geological conditions of the area and yield from the wells. These zones are i) Moderate to good potential zone ii) Poor to Moderate Potential Zone and iii) Poor Potential Zone.

\section{AQUIFER GEOMETRY AND AQUIFER}

\section{SYSTEMS}

Konkan West flowing river basin is a part of Deccan-Trap groundwater province in basaltic lava-flows where the aquifers are mostly inconsistent with complex hydrogeological system. Groundwater occurs under unconfined, semi-confined and confined aquifer conditions. In local shallow alluvium, groundwater occurs under unconfined condition.

\section{1) Unconfined Aquifer}

This category extends upto a depth of $15 \mathrm{~m}$ to $25 \mathrm{~m}$ mostly in dug well and varies in thickness from $2 \mathrm{~m}$ to $10 \mathrm{~m}$. It occupies plain areas and shows signs of weathering, jointing and fracturing of basalt flows and other rock types. The groundwater potential in this gradually sloping terrain mostly gets concentrated towards its valley.

\section{2) Semi-Confined Aquifer}

This category comprises of deeper dug-wells and dug-cumbore-wells and shallow bore- wells. These aquifers are 
found to have connectivity with water table aquifer and occur between the depths varying from $25 \mathrm{~m}$ to $50 \mathrm{~m}$. The piezometric-head in the wells / tapping these aquifers is generally much above the water-level in the nearby wells which tap the unconfined aquifers.

\section{3) Confined Aquifer}

This aquifer is tapped at depths below 50 to $80 \mathrm{~m}$ and more mostly through shallow and deep bore wells. The recharge to this aquifer is through major shear-zones, fracture zones, intersecting several flows or in a few cases through exposed-portion of the formation in the recharge area.

\section{4) Multi Layered Aquifer}

Exploratory bore wells are drilled by Central Groundwater Board and drinking water bore wells are drilled by Groundwater Survey and Development Agency, Maharashtra in Deccan Trap area. In deep bore wells deeper aquifer is encountered a depth of 60 to 100 meters. On the basis of lithology of bore wells it is observed that the flow units consist of vesicular and non vesicular units. The vesicular unit is a pervious and act as an aquifer whereas the non-vesicular unit (hard compact massive trap) is impervious and act as non-aquifer. The alternate pervious and impervious layers at deeper level, the bore well when drilled under this geological condition, water may encounter in pervious zone (aquifer).

\section{GROUND WATER RECHARGE \& DISCHARGE}

The major contribution to the groundwater recharge takes place from direct precipitation. Percolation from surface water bodies, influent seepage from streams, return flow from surface water and groundwater irrigation are the indirect agents of groundwater recharge. The soil conservation and water spreading techniques will have the necessary impact on the groundwater recharge. The recharge to groundwater body is affected by a) heavy concentration of rainfall in short period of time, b) thin soil cover and poor permeability of the formation and c) steep topographic gradient and vegetation cover.

As per the observations in Maharashtra State, the recharge components are rainfall $67 \%$, canal seepage $2 \%$, return flow from surface irrigation $12 \%$, return flow from $\mathrm{GW}$ irrigation $14 \%$, tank \& ponds $1 \%$ and water conservation structures 4\%. The recharge from surface and GW irrigation accounts for $26 \%$ of the total recharge.

Discharge of groundwater takes place through extraction of water from irrigation, domestic and other wells, effluent seepage from the major rivers, natural spring and evapotranspiration. The streams are effluent near their origin and further away down side they become influent.

\section{AQUIFER PARAMETERS OF WATER BEARING FORMATIONS}

The parameters of aquifers and the yield characteristics of wells are assessed by means of various aquifer performance tests in hydro geological surveys. The principle objective is to determine quantum of groundwater that can be safely withdrawn perennially from the aquifer.

In West flowing river basin the groundwater in the area in basaltic flow occurs under unconfined, semi confined and confined conditions. The sp. yield of the massive basalt is poor and thus significant fluctuation in water levels are observed in the area. This also results in shallow water level conditions from August to November. The sp. capacity of dug well tapping the massive basalt ranges $2.03 \mathrm{mts}$ to $55 \mathrm{lpm} / \mathrm{m}$ of drawdown whereas in moderately jointed massive basalt it ranges from 32.54 to $97.611 \mathrm{pm} / \mathrm{m}$ of drawdown. The sp. capacity of weathered basalt ranges from 110 to $130.161 \mathrm{pm} / \mathrm{m}$ of drawdown. In vesicular basalt the $\mathrm{sp}$. capacity ranges from 15 to $39.04 \mathrm{lpm} / \mathrm{m}$ of drawdown.

\section{YIELD OF DUG WELLS AND BORE WELLS}

Dug wells are used both for domestic and irrigation purposes and rarely for industrial use. Yield of the groundwater structures varies depending upon the geological formations, their location with respect to physiography, diameter, depth etc. In basaltic area, generally the vesicular part of the flow, if saturated gives better yield. Thus, the yield depends upon the saturated thickness of vesicular basalt encountered in the well. Occasionally fractured zones are also encountered which gives relatively better yield. The dug wells located in the topographic lows and morphological depression, yield comparatively more water. 
The unconfined aquifer is being developed by large diameter dug wells (1.5 to $15 \mathrm{~min}$ dia and 4 to $30 \mathrm{~m}$ deep) dug-cum bore wells (up to $60 \mathrm{~m}$ deep) with high capacity centrifugal pumps (5-10 HP). The inventory of bore wells shows the depth of casing provided was from 3 to $22 \mathrm{~m}$ below ground level for depth of bore wells ranging between 25 to $90 \mathrm{~m}$ below ground level.

For Krishna basin, the unconfined aquifer is being developed by large diameter dug wells (1.5 to $8 \mathrm{~m}$ in dia and 7 to $20 \mathrm{~m}$ deep) dug-cum bore wells (up to $60 \mathrm{~m}$ deep) with high capacity centrifugal pumps (5-10 HP). The inventory of bore wells shows the depth of casing provided was from 3 to $22 \mathrm{~m}$ below ground level for depth of bore wells ranging between 25 to $90 \mathrm{~m}$ below ground level.

In Godavari and Krishna basin Average optimum yield of dug wells in Trap ranged between $0.42 \mathrm{~m} 3 / \mathrm{hr}$ and $384 \mathrm{~m} 3 / \mathrm{hr}$ and alluvium ranged from 1.26 to $300 \mathrm{~m} 3 /$ day. The data showed wide variation in yield of bore wells between 0.5 to $43.08 \mathrm{~m} 3 /$ day in Deccan Trap and 28.80 to $54.03 \mathrm{~m} 3 /$ day in Gondwanas. For Tapi basin, the yield of dug wells tapping upper phreatic aquifer ranges between 21-337 m3 per day which have $5-15 \mathrm{~m}$ below ground level depth range borewells drilled down to $60-150 \mathrm{~m}$ depth, tapping weathered and vesicular basalt are found to yield 1.8-52 m3 per da, and the groundwater in alluvium occurs under water table semi confined and confined conditions. The dug well is deep ranging from 10-50m below ground level in depth with yield varying from 120-200 m3/day in winter and from $50-100 \mathrm{~m} 3 /$ day in summer.

\section{PARTICIPATORY GROUND WATER MANAGEMENT}

Nearly $92 \%$ area of the state is occupied by the hard rock including Basalt (82\%) and Metamorphic rocks (10\%) These rocks have poor ground water yielding (specific yield ranges from 1 to $3 \%$ ) capacity. Thus, restricting the groundwater availability as per the report on Dynamic Groundwater Resources of Maharashtra as on 2013-14 the annually replenish-able groundwater resources of the State is $31,5 \mathrm{BCM}$ against which the groundwater extraction in the state is $56 \%$ of the annually replenish-able groundwater resource, Though, the state groundwater extraction figure is $56 \%$, However, in around, one fourth part of the state, the stage of groundwater extraction is nearly or more than $100 \%$.

As per the report on Dynamic Groundwater Resources of Maharashtra as on 2013-14, out of the total 1531 watersheds of the State, 74 are categorized as Over Exploited (OE), 04 Critical (CR), 111 Semi critical (SC), 04 poor groundwater quality and rest 1338 are Safe. Groundwater being the common pool resource needs to be managed through participatory approach. Groundwater Survey and Development Agency (GSDA) has implemented the pilot projects on Aquifer based Participatory Ground water management in 52 villages from Satara, Jalna, Beed, Buldhana, Aurangabad district. GSDA is also implementing Aquifer based Participatory Ground water management in 102 villages from Amravati, Buldhana, Aurangabad, Jalgaon, Ahemadnagar, Pune and Satara. Results from these projects show that the Groundwater can be very well managed by Participatory approach. It is also learnt that Demand side interventions are more beneficial and contributing than the supply side interventions. Thus, there should be a proper mixture of supply and demand side interventions in implementation.

\section{GROUND WATER AVAILABILITY}

The ground water is one of the most important natural resources on the earth. It plays important role in maintenance of economy, environment and standard of living of any society in the state. In the absence of immediate availability of surface water sources, a large population depends upon ground water. It is equally important in river basin management. It has been the primary source of water supply for domestic, agricultural and industrial purposes. It is the single largest and most readily available source of irrigation and large irrigation (above 50\%) is depending on the ground water. In Maharashtra, a rapid growth of population and the consequent increase in irrigated agriculture, drinking water supplies and industrial needs have focused the attention of concerned to developed new water sources.The ground water assessment is carried out in the state by the Groundwater Survey of Development Agency (GSDA) in the year 2011-12. The information is compiled as water shed wise recharge annual gross groundwater draft and 
ground water availability for use of various purposes like driving irrigation and industry.

As per this assessment, given in the table below, total annual ground water recharge is $17494 \mathrm{~mm}$ and net annual ground water availability (70\%) is $12249 \mathrm{~mm}$. Annual gross ground water draft from irrigation wells, domestic wells and bore wells is $8496 \mathrm{~mm}$. The allocation for domestic and industrial water supply needs to be kept reserved, based on projected population of the year 2025 .

Table No. 5 Ground Water Assessment

\begin{tabular}{|c|c|c|c|c|c|c|}
\hline \multirow[t]{2}{*}{ Sub Basins } & \multirow{2}{*}{$\begin{array}{l}\text { No. } \\
\text { of } \\
\text { water } \\
\text { sheds }\end{array}$} & \multicolumn{2}{|c|}{$\begin{array}{l}\text { Net Recharge } \\
\text { G.W. }\end{array}$} & \multirow[t]{2}{*}{$\begin{array}{c}\text { Draft } \\
\text { in }\end{array}$} & \multirow{2}{*}{$\begin{array}{l}\text { Future } \\
\text { use in } \\
\text { Mcum. } \\
\text { (Col. 5- } \\
\text { 6) }\end{array}$} & \multirow{2}{*}{$\begin{array}{l}\text { No. of } \\
\text { addl. } \\
\text { Wells } \\
\text { for } \\
\text { Irri. }\end{array}$} \\
\hline & & $100 \%$ & $70 \%$ & & & \\
\hline 1 & 2 & 3 & 4 & 5 & 6 & 7 \\
\hline $\begin{array}{l}\text { Nashik } \\
\text { Region }\end{array}$ & 101 & 2704 & 1893 & 2126 & -233 & 889 \\
\hline Marathawada & 279 & 6797 & 4758 & 3621 & 1137 & 79887 \\
\hline Vidharbha & 427 & 7996 & 5598 & 2749 & 2849 & 190943 \\
\hline Total & 807 & 17498 & 12249 & 8496 & 3753 & 271719 \\
\hline
\end{tabular}

Source: GoM (2018), "Integrated State Water Plan For Godavari Basin of Maharashtra", WRD, Volume No. 1 Page No. 204

\section{TOTAL WATER AVAILABILITY $_{(\mathrm{Sw}+\mathrm{Gw})}$}

The surface water availability is worked out on the basis of the restricted use of water allowed by the Godavari Water Disputes Tribunal (GWDT). Similarly, though the 100\% use of ground water is permitted by the tribunal, the State Water Board (SWB) has recommended only $70 \%$ of ground water for actual use leaving $30 \%$ to be allowed for ecological purposes. Thus, the total water available will be allotted surface water and ground water.

Table No. 6 Total Water $(\mathrm{sw}+\mathrm{gw})$ Available

\begin{tabular}{|l|l|l|l|l|l|c|}
\hline Region & $\begin{array}{l}\text { Cultivabld } \\
\text { area ir } \\
\text { Ha }\end{array}$ & $\begin{array}{l}\text { Water } \\
\text { Allotted } \\
\text { (Mcum) }\end{array}$ & $\begin{array}{l}\text { GW } \\
\mathbf{7 0 \%} \text { avail. }\end{array}$ & $\begin{array}{l}\text { Total } \\
\text { water } \\
\text { MCum }\end{array}$ & $\begin{array}{l}\text { Water. } \\
\text { Cum/ha }\end{array}$ & Category \\
\hline 1 & 2 & 3 & 4 & 5 & 6 & 7 \\
\hline Nashik & 1773471 & 5837 & 1893 & 7730 & 4359 & Normal \\
\hline Marathwad & 4427526 & 5229 & 4758 & 9987 & 2256 & Deficit \\
\hline Vidarbha & 4640247 & 17957 & 5598 & 23555 & 5076 & Normal \\
\hline Total & 10841244 & 29023 & 12249 & 41271 & 3807 & Normal \\
\hline
\end{tabular}

Source: GoM (2018), “Integrated State Water Plan For Maharashtra”,

WRD, Volume No. 1 Page No. 156

From the above table, it is seen that, if the surface and ground water is considered together for deciding the category of basins, then Nashik and Vidarbha basins are coming under normal category. The classification of Marathwada is however, in deficit category only. These shows that, by considering the ground water the Marathwada I not having Satisfactory or Normal category of available water. Moreover, it is very uncertain to get the expected ground water in Marathwada region as the hard or impervious black rock is about $82 \%$ below surface of ground in this region. And hence, there are no hopes of getting good replenishment of water in the wells dug in the Marathwada region. So no one can depend on ground water as guaranteed source in Marathwada. And hence, the surface water can only be the assured source of water in Marathwada region.

\section{RECOMMENDATIONS}

In order to manage the groundwater resource in long term it is needed to focus and strongly implement following holistic Schemes in regular manner. Then only water scarcity can be managed successfully.

1) Groundwater shall be treated as social commodity and its use for drinking and irrigation purpose be done efficiently based on availability. Groundwater survey and development shall be done watershed wise and not on administrative region wise.

2) Groundwater use shall be regulated to control over exploitation. Detailed geological investigations shall be done before undertaking artificial groundwater recharge measures.

3) Water shall be managed in holistic manner.

4) There shall be a long term Village scale aquifer mapping, delineation and participatory groundwater management scheme from the Government to resolve the upcoming water issues. Since the Demand side management interventions are more beneficial than the supply side (Water conservation and Groundwater recharge) interventions. More stress shall be given on demand side interventions.

5) Groundwater monitoring network shall be made distributive, and on real time basis so as to provide real time water balance to the farmers/stake holders. This will be useful in planning water resources in the state. 
6) The Maharashtra Groundwater (Development and Management) Act, 2009 shall be implemented actively in the state, so as to regulate the over extraction of groundwater.

7) Drought-prone areas shall be made less vulnerable through soil moisture conservation measures, water harvesting practices, development of the groundwater potential including recharging.

8) As far as possible, new industries and residential habitations shall be settled in non-irrigated area.

9) Percolation tanks, check dams are constructed in that part of the state where groundwater is deeper.

\section{REFERENCES}

[1] GoI, Central Water commission report, 2013

[2] GoM, "Report of the High Level Committee on Balanced Regional Development Issues In Maharashtra, Planning Department (Dr. Kelkar Committee Report), 2013.

[3] GoM, "Maharashtra Water and Irrigation Commission Report, WRD, Volume No. 1, 1999.

[4] GoM, "Integrated State Water Plan For Maharashtra”, WRD, Volume No. 1, 2018.

[5] GoM , Maharashtra Act No. XVIII OF 2005 ,

Directorate of Government Printing and

Publications, Charni Road, Mumbai, 2005.

[6] State Ground Water and Development Act 2009. 